\section{Carcass traits in broilers fed diets containing L-glutamine and organic zinc}

\author{
Características de carcaça em frangos de corte alimentados com \\ dietas contendo L-glutamina e zinco orgânico
}

Daniela Cristina Pereira Lima' (D), Elvania Maria da Silva Costa Moreira²* (D), Sandra Regina Gomes da Silva' (D),

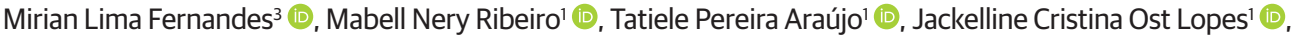
Jefferson Douglas Martins Ferreira² (D) João Batista Lopes ${ }^{4}$ (1D) \& Agustinho Valente de Figueiredo ${ }^{4}$ (D)

'Veterinarian. Programa de Pós-graduação em Ciência Animal - PPGCA, Universidade Federal do Piauí - UFPI, Teresina, PI, Brasil ${ }^{2}$ Agronomist. Programa de Pós-graduação em Ciência Animal - PPGCA, Universidade Federal do Piauí - UFPI, Teresina, PI, Brasil 'Zootechnist. Programa de Pós-graduação em Ciência Animal - PPGCA, Universidade Federal do Piauí - UFPI, Teresina, PI, Brasil ${ }^{4}$ Agronomist. Departamento de Zootecnia, Centro de Ciências Agrárias, Universidade Federal do Piauí - UFPI, Teresina, PI, Brasil

\begin{abstract}
The objective of this study was to evaluate the effect of L-glutamine and organic zinc in diets for broilers on the parameters of carcass and meat yields, chemical composition and nutrient deposition in poultry carcasses at 21 days of age. Ross chicks ( $\mathrm{n}=630$ ) were distributed in a 2 × $3+1$ completely randomized design, using levels of 1 and 2\% L-glutamine with 0, 90 and $120 \mathrm{mg}$ organic zinc/kg feed and a control diet, totaling seven treatments and five repetitions, with 18 birds each. The combination of L-glutamine and organic zinc did not influence the parameters evaluated. However, zinc supplementation alone interfered in a linearly increasing way with breast yield, in a linearly decreasing way with abdominal fat, and protein content in the carcass. Still, independently, regarding the chemical composition of poultry carcass, the level of $2 \%$ L-glutamine provided a higher concentration of dry matter and ash. Likewise, it showed the highest ash deposition. Supplementation of $2 \%$ L-glutamine in broiler diets improves the dry matter and the ash content in poultry carcasses and the inclusion of organic zinc positively interferes with the yield of breast, abdominal fat and crude protein.
\end{abstract}

Keywords: amino acid, bird, mineral, yield.

\section{Resumo}

Objetivou-se avaliar o efeito da L-glutamina e do zinco orgânico em dietas para frangos de corte sobre os parâmetros de rendimentos de carcaça e de cortes, composição química e deposição de nutrientes na carcaça de aves aos 21 dias de idade. Foram utilizados 630 pintos da linhagem Ross, distribuídas em delineamento inteiramente casualizados, em esquema 2 × $3+1$, sendo utilizados os níveis de 1 e $2 \%$ de L-glutamina com 0, 90 e 120 mg de zinco orgânico/kg de ração e uma dieta controle, totalizando sete tratamentos e cinco repetições, com 18 aves cada. A associação de L-glutamina e zinco orgânico não influenciaram nos parâmetros avaliados. No entanto, a suplementação isolada de zinco interferiu de forma linear crescente para o rendimento de peito, de forma linear decrescente para a gordura abdominal e de maneira linear decrescente quanto ao teor de proteína na carcaça. Ainda, de maneira independente, quanto à composição química na carcaça das aves, o nível de 2\% de L-glutamina proporcionou maior concentração de matéria seca e cinzas. Da mesma forma, apresentou a maior deposição de cinzas. A suplementação de $2 \%$ de L-glutamina em dietas para frangos de corte melhora o teor de matéria seca e de cinzas na carcaça das aves e a inclusão de zinco orgânico interfere positivamente no rendimento de peito, gordura abdominal e proteína bruta.

Palavras-chave: aminoácido, ave, mineral, rendimento.

\section{Introduction}

Owing the effects of thermal stress on poultry production and aiming to contribute for the country to remain in a prominent position in the production and export of chicken meat, researches have

\section{BJ $\mathrm{M}$}

Brazilian Journal of Veterinary Medicine

p-ISSN 0100-2430
How to cite: Lima, D. C. P., Moreira, E. M. S. C., Silva, S. R. G., Fernandes, M. L., Ribeiro, M. N., Araújo, T. P., Lopes, J. C. O., Ferreira, J. D. M., Lopes, J. B., \& Figueiredo, A. V. (2020). Carcass traits in broilers fed diets containing L-glutamine and organic zinc. Brazilian Journal of Veterinary Medicine, 42 e091818. https://doi.org/10.29374/2527-2179. bjvm113320

Financial support: DCPL - received scholarship from CAPES (Coordination for the Improvement of Higher Education Personnel) EMSCM SRGS, MLF, MNR, TPA, JCOL, JDMF, JBL, AVF would like to thank FAPEPI (Research Support Foundation of Piaui State) for their support in conducting this research.

Conflict of interests: No conflict of interests declared concerning the publication of this article.

Received: June 26, 2020

Accepted: July 27, 2020.

The study was carried out at Universidade Federal do Piauí - UFPI, Teresina, PI, Brasil.

\section{*Correspondence}

Elvania Maria da Silva Costa Moreira Universidade Federal do Piauí - UFPI Campus Professora Cinobelina Elvas, BR 135, Km 3, Planalto Horizonte CEP 64900-000 - Bom Jesus (PI), Brasil E-mail:ellvania@hotmail.com 
been conducted in search of new means, mainly related to nutrition, that enable the reduction of harmful effects of adverse environmental conditions, including the use of minerals and vitamins (Lopes et al., 2015) and amino acids (Nascimento et al., 2014).

Adequate feeding is essential, especially in the case of birds exposed to heat stress, since the energy provided by the consumed nutrients that would be used for production and maintenance is diverted to compensate for physiological changes caused by cold or heat.

Among the studied nutrients, the use of L-glutamine can be emphasized, since this amino acid causes an increase in protein synthesis in skeletal muscle, mainly in the cuts, thigh and drumstick, and provides beneficial effects on performance parameters, carcass yield, weight of lymphoid organs and intestinal morphology (Fasina et al., 2010). Another option is the mineral zinc, as it is associated with the reduction of abdominal fat and triglyceride levels and improvements in carcass yield in broilers (Jahanian \& Rasouli, 2015).

Thus, as the supplementation of L-glutamine and zinc has not been tested in the nutrition of non-ruminant animals, the goal of this study was to evaluate the effect of L-glutamine and organic zinc in diets for broiler chickens on carcass and cut yields, chemical composition and nutrient deposition in the carcass of birds at 21 days of age.

\section{Material and methods}

The experiment was carried out from June to July 2015. The experimental protocol was evaluated by the Ethics Committee on Animal Experimentation (CEEUA) at the Federal University of Piauí (UFPI), with approved opinion 087/12.

Ross broiler chicks ( $\mathrm{n}=630$ ), male and female, from 1 to 21 days of age, with an initial mean weight of $38.17 \pm 0.77 \mathrm{~g}$, were distributed in a $2 \times 3+1$ factorial, completely randomized design, consisting of two levels of L-glutamine (1 and 2\%) combined with three levels of zinc (0, 90 and $120 \mathrm{mg} / \mathrm{kg}$ feed), in organic form Availa Zinco, a control diet and five repetitions with 18 birds each.

Chicks were given a pre-starter diet until 7 days (Table 1) and another for the starter phase (Table 2), from 8 to 21 days of age. Diets were formulated to meet the nutritional requirements recommended by Rostagno et al. (2011), except for organic zinc that was added to diets to replace inert material, while L-glutamine was introduced in the formulation of diets. Birds received feed and water ad libitum. It is worth mentioning that the values of metabolizable energy of L-glutamine were obtained based on National Research Council (1994), and those of crude protein were analyzed at the Animal Nutrition Laboratory of the Animal Science Department/UFPI.

Eighteen birds ( 9 males and 9 females) were housed in $2.7 \mathrm{~m}^{2}$ cages, equipped with tubular feeders and pendant drinking fountains, located in masonry sheds covered with ceramic tiles and cemented floors.

To control the entry of sunlight and air currents, curtains were installed around the shed. Temperature and relative humidity of the air in the sheds were controlled by means of maximum and minimum thermometers and dry and wet bulb thermo-hygrometer, kept at the center of the shed at the height of the birds' back. Thermometers were read three times a day $(8,13$ and 16 hours), with the exception of maximum and minimum, whose reading was performed only in the morning, throughout the experimental period. These data were later converted into the Globe Temperature and Humidity Index (ITGU), as proposed by Buffington et al. (1981). The light program adopted was continuous (24 hours of natural + artificial light) using 60W incandescent lamps.

On the 21st day, the experiment was completed and two birds, weighing close to the average of each box, were fasted for 12 hours and, subsequently, slaughtered (stunning, bleeding and plucking) as recommended by the Regulation of Industrial and Sanitary Inspection of Products of Animal Origin (Brasil, 2017).

Carcass yield was determined by the relationship of eviscerated carcass weight to body weight of birds at slaughter, and the cuts and abdominal fat (adipose tissue around the cloacal pouch, proventricle, gizzard and cloaca) were measured in relation to the weight of the eviscerated carcass.

After weighing, one carcass of each repetition, totaling 5 per treatment, was packed in duly identified plastic bags and stored in a freezer, afterwards they were cut and ground in an industrial meat mill, lyophilized for 72 hours and ground in a knife mill (average particle size $1 \mathrm{~mm}$ ) and stored in plastic containers properly sealed and identified for further laboratory analysis. 
Table 1. Percentage and calculated composition of experimental diets for broilers in the pre-starter phase (1 to 7 days of age).

\begin{tabular}{|c|c|c|c|c|c|c|c|}
\hline \multirow{2}{*}{ Ingredient (\%) } & \multicolumn{7}{|c|}{ Levels of L-glutamine (\%)/ zinc (mg/kg) } \\
\hline & $0 / 0$ & $1 / 0$ & $1 / 90$ & $1 / 120$ & $2 / 0$ & $2 / 90$ & $2 / 120$ \\
\hline Corn & 52.000 & 54.500 & 54.500 & 54.500 & 57.400 & 57.400 & 57.400 \\
\hline Soybean meal 48\% & 33.430 & 30.170 & 30.170 & 30.170 & 26.810 & 26.810 & 26.810 \\
\hline Vegetable oil & 4.827 & 4.322 & 4.322 & 4.322 & 3.678 & 3.678 & 3.678 \\
\hline Dicalcium phosphate & 1.770 & 1.805 & 1.805 & 1.805 & 1.842 & 1.842 & 1.842 \\
\hline Calcitic limestone & 0.975 & 0.975 & 0.975 & 0.975 & 0.980 & 0.980 & 0.980 \\
\hline $\mathrm{NaCl}$ & 0.508 & 0.508 & 0.508 & 0.508 & 0.510 & 0.510 & 0.510 \\
\hline L-Lysine - HCL (79\%) (79\%) & 0.063 & 0.168 & 0.168 & 0.168 & 0.278 & 0.278 & 0.278 \\
\hline L-Tryptophan (98\%) & 0.000 & 0.000 & 0.000 & 0.000 & 0.011 & 0.011 & 0.011 \\
\hline Valine & 0.155 & 0.215 & 0.215 & 0.215 & 0.277 & 0.277 & 0.277 \\
\hline Threonine & 0.007 & 0.055 & 0.055 & 0.055 & 0.104 & 0.104 & 0.104 \\
\hline Nucleus $^{1}$ & 6.000 & 6.000 & 6.000 & 6.000 & 6.000 & 6.000 & 6.000 \\
\hline Zinc $^{2}$ & 0.000 & 0.000 & 0.090 & 0.120 & 0.000 & 0.090 & 0.120 \\
\hline L-glutamine ${ }^{3}$ & 0.000 & 1.000 & 1.000 & 1.000 & 2.000 & 2.000 & 2.000 \\
\hline Kaolin & 0.264 & 0.282 & 0.192 & 0.162 & 0.109 & 0.019 & 0.000 \\
\hline TOTAL & 100 & 100 & 100 & 100 & 100 & 100 & 100 \\
\hline \multicolumn{8}{|c|}{ Calculated composition } \\
\hline Crude protein (\%) & 22.399 & 22.401 & 22.401 & 22.401 & 22.402 & 22.402 & 22.402 \\
\hline ME (kcal/kg) & 2959.996 & 2959.997 & 2959.997 & 2959.997 & 2960.001 & 2960.001 & 2960.001 \\
\hline Digestible lysine (\%) & 1.324 & 1.324 & 1.324 & 1.324 & 1.325 & 1.325 & 1.325 \\
\hline Digestible methionine & 0.669 & 0.653 & 0.653 & 0.653 & 0.637 & 0.637 & 0.637 \\
\hline Digestible threonine & 0.861 & 0.861 & 0.861 & 0.861 & 0.862 & 0.862 & 0.862 \\
\hline Digestible tryptophan digestível (\%) & 0.253 & 0.234 & 0.234 & 0.234 & 0.226 & 0.226 & 0.226 \\
\hline Valine (\%) & 1.020 & 1.019 & 1.019 & 1.019 & 1.020 & 1.020 & 1.020 \\
\hline Calcium (\%) & 0.921 & 0.920 & 0.920 & 0.920 & 0.921 & 0.921 & 0.921 \\
\hline Available phosphorus (\%) & 0.470 & 0.470 & 0.470 & 0.470 & 0.471 & 0.471 & 0.471 \\
\hline Sodium (\%) & 0.219 & 0.219 & 0.219 & 0.219 & 0.219 & 0.219 & 0.219 \\
\hline Zinc (mg/kg) & 146.869 & 145.961 & 235.961 & 265.961 & 145.094 & 235.094 & 265.094 \\
\hline L-glutamine (\%) & 0.000 & 1.007 & 1.007 & 1.007 & 2.014 & 2.014 & 2.014 \\
\hline
\end{tabular}

'Guarantee levels per kg of product: moisture (max.) 120g; crude protein (min.) 340g; ether extract 45g; crude fiber 10g; mineral matter 300g; calcium 22g; phosphorus 5,200mg; methionine 65g; Iysine 45g; threonine 27g; tryptophan 3,780mg; vitamin A 250,000 IU; vitamin D360,000 IU; vitamin E 833 IU; vitamin K350mg; vitamin B1 50mg; vitamin B2 133mg; vitamin B6 83mg; vitamin B12 333mg; niacin 100mg; pantothenic acid 233mg; folic acid 25mg; biotin 0.66mg; choline 5,900mg; manganese 1.666mg; 1600mg zinc; chelated zinc 400mg; iron 837mg; copper 1,667mg; iodine 21mg; selenium 6mg; BHT 1,764 mg; phytase 8,335UI; 2,500Ul protease; amylase 2,500UI; $\beta$-glucanase 2,083Ul; xylanase 4,165Ul; cellulase 3,750Ul; senduramycin + nicarbazin $1.100 \mathrm{mg} .{ }^{2}$ Availa'Zinco 100,000mg $/ \mathrm{kg} .{ }^{3}$ Metabolizable energy based on National Research Council (1994) and crude protein analyzed (119.74\%). ME = Energia metabolizável = Metabolizable energy. $\mathrm{HCl}=$ Ácido clorídrico $=$ hydrochloric acid.

Analysis of dry matter, crude protein, ash content and ether extract were performed at the Animal Nutrition Laboratory of the Animal Science Department/UFPI, according to the methodology of Silva \& Queiroz (2002). The same procedure was carried out at the beginning of the phase, on the 1st day of age, with 10 birds with an average weight similar to those subjected to experimental treatments. These data were used to determine the chemical composition and deposition of nutrients in the carcass.

To determine the deposition rate of water, protein, ether extract and mineral matter in the carcass, we used the methodology adapted from Fraga et al. (2008). 
Table 2. Percentage and calculated composition of experimental diets for broilers in the starter phase (8 to 21 days of age).

\begin{tabular}{|c|c|c|c|c|c|c|c|}
\hline \multirow{2}{*}{ Ingredient } & \multicolumn{7}{|c|}{ Levels of L-glutamine (\%)/ zinc (mg/kg) } \\
\hline & $0 / 0$ & $1 / 0$ & $1 / 90$ & $1 / 120$ & $2 / 0$ & $2 / 90$ & $2 / 120$ \\
\hline Corn & 58.300 & 60.500 & 60.500 & 60.500 & 62.600 & 62.600 & 62.600 \\
\hline Soybean meal 48\% & 34.414 & 31.400 & 31.400 & 31.400 & 28.246 & 28.246 & 28.246 \\
\hline Vegetable oil & 3.259 & 2.854 & 2.854 & 2.854 & 2.484 & 2.484 & 2.484 \\
\hline Dicalcium phosphate & 1.530 & 1.560 & 1.560 & 1.560 & 1.600 & 1.600 & 1.600 \\
\hline Calcitic limestone & 0.907 & 0.907 & 0.907 & 0.907 & 0.907 & 0.907 & 0.907 \\
\hline $\mathrm{NaCl}$ & 0.482 & 0.482 & 0.482 & 0.482 & 0.482 & 0.482 & 0.482 \\
\hline L-Lysine - HCL (79\%) & 0.000 & 0.000 & 0.000 & 0.000 & 0.082 & 0.082 & 0.082 \\
\hline L-Tryptophan (98\%) & 0.000 & 0.000 & 0.000 & 0.000 & 0.002 & 0.002 & 0.002 \\
\hline Valine & 0.029 & 0.085 & 0.085 & 0.085 & 0.145 & 0.145 & 0.145 \\
\hline Threonine & 0.038 & 0.080 & 0.080 & 0.080 & 0.127 & 0.127 & 0.127 \\
\hline Mineral vitamin Premix aminoacídico ${ }^{1}$ & 1.000 & 1.000 & 1.000 & 1.000 & 1.000 & 1.000 & 1.000 \\
\hline Zinc $^{2}$ & 0.000 & 0.000 & 0.090 & 0.120 & 0.000 & 0.090 & 0.120 \\
\hline L-glutamin ${ }^{3}$ & 0.000 & 1.000 & 1.000 & 1.000 & 2.000 & 2.000 & 2.000 \\
\hline Kaolin & 0.041 & 0.132 & 0.042 & 0.012 & 0.325 & 0.235 & 0.205 \\
\hline Total & 100 & 100 & 100 & 100 & 100 & 100 & 100 \\
\hline \multicolumn{8}{|c|}{ Calculated composition } \\
\hline Crude protein (\%) & 21.200 & 21.198 & 21.198 & 21.198 & 21.201 & 21.201 & 21.201 \\
\hline $\mathrm{ME}(\mathrm{kcal} / \mathrm{kg})$ & 3050.003 & 3049.998 & 3049.998 & 3049.998 & 3050.001 & 3050.001 & 3050.001 \\
\hline Digestible lysine (\%) & 1.211 & 1.134 & 1.134 & 1.134 & 1.117 & 1.117 & 1.117 \\
\hline Digestible methionine (\%) & 0.608 & 0.593 & 0.593 & 0.593 & 0.577 & 0.577 & 0.577 \\
\hline Digestible threonine(\%) & 0.792 & 0.790 & 0.790 & 0.790 & 0.790 & 0.790 & 0.790 \\
\hline Digestible tryptophan (\%) & 0.239 & 0.222 & 0.222 & 0.222 & 0.206 & 0.206 & 0.206 \\
\hline Digestible Valine (\%) & 0.937 & 0.936 & 0.936 & 0.936 & 0.937 & 0.937 & 0.937 \\
\hline Calcium (\%) & 0.841 & 0.840 & 0.840 & 0.840 & 0.840 & 0.840 & 0.840 \\
\hline Available phosphorus (\%) & 0.401 & 0.400 & 0.400 & 0.400 & 0.401 & 0.401 & 0.401 \\
\hline Sodium (\%) & 0.210 & 0.210 & 0.210 & 0.210 & 0.210 & 0.210 & 0.210 \\
\hline Zinc (mg/kg) & 88.568 & 87.703 & 177.70 & 207.703 & 86.758 & 176.758 & 206.758 \\
\hline L-glutamine (\%) & 0.000 & 1.007 & 1.007 & 1.007 & 2.014 & 2.014 & 2.014 \\
\hline
\end{tabular}

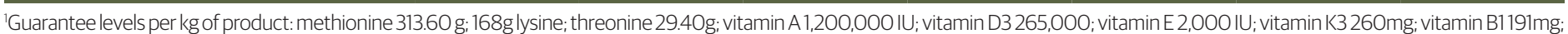

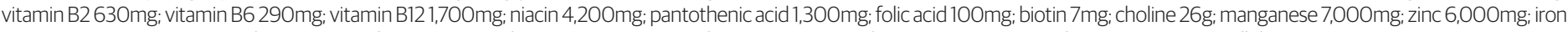

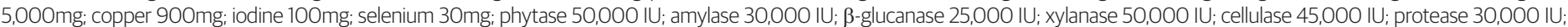

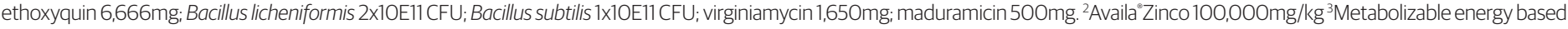
on National Research Council (1994) and crude protein analyzed (119.74\%).

Data of relative air humidity, temperature and globe temperature and humidity index were presented as mean and standard deviation. The other parameters were tested by analysis of variance and regression test, as well as the SNK test. When comparing each treatment with the control diet, Dunnett's test was applied, according to the PROC GLM procedures of SAS software (SAS Institute, 2013). $\alpha=0.05$ was used. 


\section{Results}

The mean values recorded during the phase from 1 to 7 days of age of the birds were: $67.61 \pm 12.84 \%$ relative humidity of the air; $27.60 \pm 0.49^{\circ} \mathrm{C}$ for ambient temperature and $80.13 \pm 2.48$ for ITGU. From the second and third week of life of the birds, the mean values obtained were $66.76 \pm 16.99 \%$; $27.73 \pm 0.59^{\circ} \mathrm{C}$ and $79.5 \pm 3.72$, respectively.

There was no interaction ( $\mathrm{P}>0.05$ ) between L-glutamine and organic zinc for yield of carcass, breast, thigh, drumstick, wing+wingette and abdominal fat (Table 3).

Table 3. Carcass yield, cuts and abdominal fat of broilers at 21 days of age, fed different levels of L-glutamine and organic zinc.

\begin{tabular}{|c|c|c|c|c|c|c|c|c|}
\hline \multirow{2}{*}{ Control } & \multirow{2}{*}{ Glutamine (\%) } & \multicolumn{3}{|c|}{ Zinc (mg/kg) } & \multirow{2}{*}{ Mean } & \multirow{2}{*}{ CV (\%) } & \multicolumn{2}{|c|}{ P-value } \\
\hline & & 0 & 90 & 120 & & & $\mathbf{L}$ & $\mathbf{Q}$ \\
\hline \multicolumn{9}{|c|}{ Carcass } \\
\hline \multirow{3}{*}{79.04} & 1 & 80.43 & 79.22 & 80.27 & 79.97 & \multirow{2}{*}{1.44} & \multirow{2}{*}{0.947} & \multirow{2}{*}{0.588} \\
\hline & 2 & 79.08 & 79.77 & 79.17 & 79.34 & & & \\
\hline & Mean & 79.75 & 79.49 & 79.72 & & & & \\
\hline \multicolumn{9}{|c|}{ Breast } \\
\hline \multirow{3}{*}{28.73} & 1 & 27.90 & 29.62 & 29.52 & 29.01 & \multirow{2}{*}{3.15} & \multirow{2}{*}{0.001} & \multirow{2}{*}{0.294} \\
\hline & 2 & 28.68 & 29.17 & 29.95 & 29.27 & & & \\
\hline & Mean & 28.96 & 29.39 & 29.73 & & & & \\
\hline \multicolumn{9}{|c|}{ Drumstick } \\
\hline \multirow{3}{*}{10.03} & 1 & 11.72 & 11.64 & 11.71 & 11.69 & \multirow{2}{*}{4.94} & \multirow{2}{*}{0.748} & \multirow{2}{*}{0.385} \\
\hline & 2 & 11.35 & 11.91 & 11.53 & 11.60 & & & \\
\hline & Mean & 11.53 & 11.77 & 11.62 & & & & \\
\hline \multicolumn{9}{|c|}{ Thigh } \\
\hline \multirow{3}{*}{13.06} & 1 & 13.44 & 14.01 & 13.02 & 13.49 & \multirow{2}{*}{6.04} & \multirow{2}{*}{0.161} & \multirow{2}{*}{0.171} \\
\hline & 2 & 13.45 & 13.24 & 12.83 & 13.17 & & & \\
\hline & Mean & 13.44 & 13.62 & 12.92 & & & & \\
\hline \multicolumn{9}{|c|}{ Wing+wingette } \\
\hline \multirow{4}{*}{11.54} & 1 & 10.92 & $10.08^{*}$ & 10.96 & 10.65 & \multirow{2}{*}{0.05} & \multirow[t]{2}{*}{0.934} & \multirow[t]{2}{*}{0.051} \\
\hline & 2 & 10.61 & 11.09 & 10.70 & 10.77 & & & \\
\hline & Mean & 10.76 & 10.54 & 10.83 & & & & \\
\hline & \multicolumn{8}{|c|}{ Abdominal fat } \\
\hline 115 & 1 & 1.53 & 0.89 & 0.90 & 1.10 & 2123 & O 017 & 0144 \\
\hline 1.15 & 2 & 1.38 & 1.01 & 0.91 & 1.05 & 21.23 & $0.01 /$ & 0.144 \\
\hline & Mean & 1.46 & 0.95 & 0.90 & & & & \\
\hline
\end{tabular}

Mean values followed by an asterisk differ from the control treatment by Dunnett's test $(P<0.05)$. Mean values followed by different lowercase letters, in the same column, for the same variable are significantly different by SNK test ( $P>0.05$ ). L, Q: probability of linear and quadratic order related to the inclusion of zinc in the diet. CV = coeficiente de variação $=$ coefficient of variation. * = Mean values followed by an asterisk differ from the control treatment by Dunnett's test $(P<0.05)$

In the comparison of the control treatment with the others, birds supplemented with $1 \%$ L-glutamine combined with $90 \mathrm{mg}$ organic zinc/kg feed, presented lower $(\mathrm{P}<0.05)$ yield of wing+wingette.

In isolation, zinc levels provided an increasing linear effect for breast yield and decreasing linear effect for abdominal fat yield, according to the equations: $Y=28.943+0.006 x\left(R^{2}=0.95\right)$ and $Y=1.4455-0.0048 x\left(R^{2}=0.97\right)$, respectively. 
There was no interaction ( $\mathrm{P}>0.05)$ between L-glutamine and organic zinc for the chemical composition of broiler carcass (Table 4).

Table 4. Chemical composition of broiler carcasses fed different levels of L-glutamine and organic zinc at 21 days of age.

\begin{tabular}{|c|c|c|c|c|c|c|c|c|}
\hline \multirow{2}{*}{ Control } & \multirow{2}{*}{ Glutamine (\%) } & \multicolumn{3}{|c|}{ Zinc (mg/kg) } & \multirow[t]{2}{*}{ Mean } & \multirow{2}{*}{$\frac{\mathrm{CV}}{(\%)}$} & \multicolumn{2}{|c|}{ Pvalue } \\
\hline & & 0 & 90 & 120 & & & $\mathbf{L}$ & Q \\
\hline \multicolumn{9}{|c|}{ Chemical composition (\%) } \\
\hline \multicolumn{9}{|c|}{ Dry matter } \\
\hline \multirow{3}{*}{29.40} & 1 & 29.38 & 29.50 & 30.04 & $29.66 b$ & \multirow{2}{*}{2.40} & \multirow{2}{*}{0.817} & \multirow{2}{*}{0.544} \\
\hline & 2 & $31.47^{*}$ & $31.07^{*}$ & 30.96* & $31.16 a$ & & & \\
\hline & Mean & 30.54 & 30.28 & 30.50 & & & & \\
\hline \multicolumn{9}{|c|}{ Protein } \\
\hline \multirow{2}{*}{55.16} & 1 & 56.85 & 56.66 & 56.41 & 56.66 & \multirow{2}{*}{5.40} & \multirow{2}{*}{0.037} & \multirow{2}{*}{0.367} \\
\hline & 2 & $58.79^{*}$ & 58.42 & 55.01 & 57.36 & & & \\
\hline & Mean & 57.77 & 57.54 & 55.71 & & & & \\
\hline \multicolumn{9}{|c|}{ Ether extract } \\
\hline \multirow{2}{*}{37.35} & 1 & 34.06 & $29.56^{*}$ & 33.41 & 32.34 & \multirow{2}{*}{12.11} & \multirow{2}{*}{0.263} & \multirow{2}{*}{0.121} \\
\hline & 2 & $29.47^{*}$ & 31.13 & 34.10 & 31.57 & & & \\
\hline & Mean & 31.77 & 30.35 & 33.76 & & & & \\
\hline \multicolumn{9}{|c|}{ Ash } \\
\hline \multirow{3}{*}{8.88} & 1 & $7.25^{*}$ & 7.89 & 8.12 & $7.75 b$ & \multirow{2}{*}{12.51} & \multirow{2}{*}{0.197} & \multirow{2}{*}{0.583} \\
\hline & 2 & 9.00 & 9.05 & 8.92 & 8.99a & & & \\
\hline & Mean & 8.12 & 8.47 & 8.50 & & & & \\
\hline
\end{tabular}

Mean values followed by an asterisk differ from the control treatment by Dunnett's test $(P<0.05)$. Mean values followed by different lowercase letters, in the same column, for the same variable, are significantly different by SNK test $(P>0.05)$. L, Q: probability of linear and quadratic order related to the inclusion of zinc in the diet. ${ }^{*}=$ Mean values followed by an asterisk differ from the control treatment by Dunnett's test $(P<0.05)$.

Comparing the control diet with the others, animals supplemented with a combination of $2 \%$ L-glutamine and 0, 90 and $120 \mathrm{mg}$ organic zinc/kg feed showed higher values $(\mathrm{P}<0.05)$ of dry matter in the carcass, and in isolation, $2 \%$ supplemental L-glutamine also provided a higher concentration for this variable.

As for the protein content in the carcass, it was observed that when confronting the control treatment with the others, birds fed $2 \% \mathrm{~L}$-glutamine and $0 \mathrm{mg}$ organic zinc/ $\mathrm{kg}$ feed showed higher values $(\mathrm{P}<0.05)$ and independently, zinc levels were influenced $(\mathrm{P}<0.05)$ in a linearly decreasing way, according to equation $\ddot{Y}=57.976-0.0138 x\left(R^{2}=0.58\right)$.

For the composition of ether extract in the carcass, treatments with $1 \%$ L-glutamine combined with 90mg zinc/kg feed and 2\% L-glutamine without the addition of zinc, showed lower values $(\mathrm{P}<0.05)$ than the control.

Regarding the ash content in the carcass, the treatment with $1 \%$ L-glutamine without the addition of zinc showed a lower $(\mathrm{P}<0.05)$ ash concentration than the control group. And for isolated levels of L-glutamine, it occurred in a similar way (lower content).

The deposition of water, protein, ether extract, protein/extract ratio and ash in the carcass were not affected $(\mathrm{P}>0.05)$ by the combination of L-glutamine and zinc in the diet. In addition, deposition of water and protein in the carcass also did not differ $(\mathrm{P}>0.05)$ from the control treatment (Table 5).

Birds supplemented with 2\% L-glutamine without the addition of supplemental zinc showed less $(\mathrm{P}<0.05)$ deposition of ether extract and higher $(\mathrm{P}<0.05)$ protein/ether extract ratio when compared to control treatment. 
Table 5. Nutrient deposition in broiler carcasses fed different levels of L-glutamine and organic zinc at 21 days of age.

\begin{tabular}{|c|c|c|c|c|c|c|c|c|}
\hline \multirow{2}{*}{ Control } & \multirow{2}{*}{ Glutamine (\%) } & \multicolumn{3}{|c|}{ Zinc (mg/kg) } & \multirow[t]{2}{*}{ Mean } & \multirow{2}{*}{$\begin{array}{c}\mathrm{CV}(\%) \\
(\%)\end{array}$} & \multicolumn{2}{|c|}{ P-value } \\
\hline & & 0 & 90 & 120 & & & $\mathbf{L}$ & $\mathbf{Q}$ \\
\hline \multicolumn{9}{|c|}{ Nutrient deposition (g/kg) } \\
\hline \multicolumn{9}{|c|}{ Water } \\
\hline \multirow{2}{*}{457.97} & 1 & 474.28 & 454.398 & 440.83 & 456.51 & \multirow{2}{*}{8.87} & \multirow{2}{*}{0.808} & \multirow{2}{*}{0.944} \\
\hline & 2 & 417.49 & 439.588 & 459.67 & 438.92 & & & \\
\hline & Mean & 445.89 & 446.990 & 450.25 & & & & \\
\hline \multicolumn{9}{|c|}{ Protein } \\
\hline \multirow{3}{*}{357.95} & 1 & 386.02 & 366.14 & 355.95 & 369.37 & \multirow{2}{*}{10.18} & \multirow{2}{*}{0.346} & \multirow{2}{*}{0.750} \\
\hline & 2 & 359.11 & 374.16 & 366.36 & 366.803 & & & \\
\hline & Mean & 373.28 & 370.15 & 361.16 & & & & \\
\hline \multicolumn{9}{|c|}{ Ether extract } \\
\hline \multirow{2}{*}{244.74} & 1 & 211.31 & 198.83 & 197.48 & 202.54 & \multirow{2}{*}{17.79} & \multirow{2}{*}{0.521} & \multirow{2}{*}{0.877} \\
\hline & 2 & $179.61^{*}$ & 206.84 & 214.31 & 200.260 & & & \\
\hline & Mean & 195.46 & 202.84 & 205.90 & & & & \\
\hline \multicolumn{9}{|c|}{ Protein/ether extract } \\
\hline \multirow{2}{*}{1.46} & 1 & 1.90 & 1.88 & 1.85 & 1.881 & \multirow{2}{*}{17.10} & \multirow{2}{*}{0.208} & \multirow{2}{*}{0.813} \\
\hline & 2 & $2.04^{*}$ & 1.81 & 1.71 & 1.845 & & & \\
\hline & Mean & 1.96 & 1.85 & 1.78 & & & & \\
\hline \multicolumn{9}{|c|}{ Ash } \\
\hline \multirow{3}{*}{58.37} & 1 & $49.34^{*}$ & 51.66 & 51.91 & $50.97 b$ & \multirow{2}{*}{14.35} & \multirow{2}{*}{0.070} & \multirow{2}{*}{0.906} \\
\hline & 2 & 55.90 & 58.70 & 62.54 & 59.05a & & & \\
\hline & Média & 52.62 & 55.18 & 57.22 & & & & \\
\hline
\end{tabular}

Mean values followed by an asterisk differ from the control treatment by Dunnett's test $(P<0.05)$. Mean values followed by different lowercase letters, in the same column, for the same variable, are significantly different by SNK test $(P>0.05)$. L, Q: probability of linear and quadratic order related to the inclusion of zinc in the diet. ${ }^{*}=$ Mean values followed by an asterisk differ from the control treatment by Dunnett's test $(P<0.05)$.

As for the ash content deposited in the carcass, the control group showed a higher $(\mathrm{P}<0.05)$ ash deposition than the $1 \%$ treatment of $\mathrm{L}$-glutamine without the addition of zinc. And in relation to the isolated levels of L-glutamine, the addition of $2 \%$ of this amino acid showed higher $(\mathrm{P}<0.05)$ ash deposition when compared to the level of $1 \%$.

\section{Discussion}

After analyzing the relative humidity, ambient temperature and ITGU data, it was noticed that the birds during the experimental period ( 1 to 21 days old) were exposed to natural conditions of thermal discomfort due to the heat in certain periods of the day, since the comfort zone was changed to those considered ideal for broilers according to Souza et al. (2019), from 60 to 70\%, Paulino et al. (2019), from 32 to $28^{\circ} \mathrm{C}$, and Staub et al. (2016), from 65 to 77.

In contrast to the results obtained here, studies conducted by Lopes et al. (2019) reported no differences $(\mathrm{P}>0.05)$ for wing yield when combining supplementation of organic zinc and vitamin $\mathrm{E}$ in diets for broilers.

Although zinc levels do not influence the carcass yield, it provided effects for breast yield, demonstrating that the supplementation of this mineral is influenced by many factors, not only by environmental conditions, but also by differences in magnitude, duration and type of stress that birds are subjected to (Silva et al., 2015). 
The linear reduction in abdominal fat observed for zinc levels can be attributed to the bird's line, since according to Farran et al. (2000), Ross broilers have lower levels of abdominal fat when compared to Arbor Acres animals.

In contrast to the results of this study, Silva et al. (2015) found no increases in dry matter values in broiler carcasses.

Higher concentration of protein in the carcass, with the supplementation of 2\% L-glutamine without the addition of supplemental zinc, was expected, since the increase in the intramuscular concentration of this amino acid has the ability to inhibit muscle proteolysis (MacLennan et al., 1988), providing a higher concentration of this nutrient in the carcass. Likewise, Dai et al. (2009) under heat stress conditions, also found an increase in the crude protein content of broiler carcasses at 42 days of age, with the supplementation of L-glutamine in the bird's diet.

The results of this research confirm information about the increase in protein and the decrease in fat accumulation. This reduction in body ether extract suggests an increase in the efficiency of protein synthesis and accumulation of muscle mass.

Lower concentration of ash in poultry carcass supplemented with L-glutamine may be due to the lower dry matter content observed for this treatment.

In this study, zinc levels did not interfere with the deposition of ash in the carcass, which is in accordance with data from Trindade Neto et al. (2010), who also did not find effects of levels of 43 and $253 \mathrm{mg}$ zinc/kg feed on this parameter in broilers. On the other hand, Sunder et al. (2008) observed that the concentration of ash in the tibia of broilers decreases with the addition of 320 $\mathrm{mg}$ zinc/kg, which indicates the possibility of the negative effect of high concentrations of zinc on bone mineralization.

Although 2\% L-glutamine supplementation provided a higher protein concentration in the carcass (Table 4), this was not sufficient to increase the protein deposition in the carcass (Table 5), disagreeing with Watford \& Wu (2005), who claimed that the addition of this amino acid increases protein synthesis in skeletal muscle. In contrast, Furlan et al. (2004) report that protein deposition in the carcass is pre-established by the bird, according to its genetic information, that is, there is a limit to daily protein deposition, which cannot be compensated for by the diet.

The higher protein/ether extract ratio indicates a positive change in carcass composition, since excess fat, in addition to reducing the carcass yield and the feed efficiency of the birds, also leads the consumer to reject chicken meat, since the market today requires leaner meat (Gaya et al., 2006).

The lack of interaction between the levels of supplementation of L-glutamine and zinc on the deposition of nutrients in the carcass may have occurred because experimental diets were formulated to be isoenergetic and isoproteic, which provided the balanced intake of metabolizable energy and crude protein by animals.

\section{Conclusions}

The combination of L-glutamine and organic zinc in diets for broilers did not influence the carcass and cut yields, chemical composition and nutrient deposition in the carcass of birds at 21 days of age. Nevertheless, supplementation of $2 \%$ L-glutamine alone improves the dry matter and ash content in poultry carcasses, and the inclusion of organic zinc positively interferes with the yield of breast, abdominal fat and crude protein.

\section{Acknowledgements}

The authors would like to thank CAPES (Coordination for the Improvement of Higher Education Personnel) and FAPEPI (Research Support Foundation of Piauí State) for their support in conducting this research.

\section{References}

Brasil. (2017). Regulamento da Inspeção Industrial e Sanitária de Produtos de Origem Animal - RIISPOA. Brasília.

Buffington, D. E., Collazo-Arocho, A., Canton, G. H., Pitt, D., Thatcher, W. W., \& Collier, R. J. (1981). Black globe-humidity index (BGHI) as comfort equation for dairy cows. Transactions of the ASAE. American Society of Agricultural Engineers, 24(3), 711-714. http://dx.doi.org/10.13031/2013.34325. 
Dai, S. F., Wang, L. K., Wen, A. Y., Wang, L. X., \& Jin, G. M. (2009). Dietary glutamine supplementation improves growth performance, meat quality and colour stability of broilers under heat stress. British Poultry Science, 50(3), 333-340. http://dx.doi.org/10.1080/00071660902806947. PMid:19637033.

Farran, M. T., Khalil, R. F., Uwayjan, M. G., Ashkarian, V. M., \& Hajj, R. N. (2000). Performance and carcass quality of commercial broiler strains. Journal of Applied Poultry Research, 9(2), 252-257. http://dx.doi.org/10.1093/ japr/9.2.252.

Fasina, Y. O., Bowers, J. B., Hess, J. B., \& Mckee, S. R. (2010). Effect of dietary glutamine supplementation on Salmonella colonization in the ceca of young broiler chicks. Poultry Science, 89(5), 1042-1048. http://dx.doi. org/10.3382/ps.2009-00415. PMid:20371858.

Fraga, A. L., Moreira, I., Furlan, A. C., Bastos, A. O., Oliveira, R. P., \& Murakami, A. E. (2008). Lysine requirement of starting barrows from two genetic groups fed on low crude protein diets. Brazilian Archives of Biology and Technology, 51(1), 49-56. http://dx.doi.org/10.1590/S1516-89132008000100007.

Furlan, R. L., Faria Filho, D. E., Rosa, P. S., \& Macari, M. (2004). Does low-protein diet improve broiler performance under heat stress conditions? Brazilian Journal of Poultry Science, 6(2), 71-86. http://dx.doi.org/10.1590/ S1516-635X2004000200001.

Gaya, L. G., Mourão, G. B., \& Ferraz, J. B. S. (2006). Aspectos genético-quantitativos de características de desempenho, carcaça e composição corporal em frangos. Ciência Rural, 36(2), 709-716. http://dx.doi.org/10.1590/ S0103-84782006000200058.

Jahanian, R., \& Rasouli, E. (2015). Effects of dietary substitution of zincmethionine for inorganic zinc sources on growth performance, tissue zinc accumulation and some blood parameters in broiler chicks. Journal of Animal Physiology and Animal Nutrition, 99(1), 50-58. http://dx.doi.org/10.1111/jpn.12213. PMid:24924648.

Lopes, J. C. O., Ferreira, J. D. M., Figueiredo, A. V., Lopes, J. B., Maia, S. F., Ribeiro, M. N., \& Aguiar, V. S. L. (2019). Bioquímica sérica e carcaça de frangos de corte, em condições naturais de calor, suplementados com zinco orgânico e vitamina E. Revista Agrária Acadêmica, 2(3), 1-9. http://dx.doi.org/10.32406/v2n32019/193-201/agrariacad.

Lopes, J. C. O., Figueirêdo, A. V., Lopes, J. B., Lima, D. C. P., Ribeiro, M. N., \& Lima, V. B. S. (2015). Zincand vitamin E in diets for broilers reared under heat stress. Revista Brasileira de Saúde e Produção Animal, 16(2), 350-364. http://dx.doi.org/10.1590/S1519-99402015000200010.

MacLennan, P. A., Smith, K., Weryk, B., Watt, P. W., \& Rennie, M. J. (1988). Inhibition of protein breakdown by glutamine in perfused rat skeletal muscle. FEBS Letters, 237(1-2), 133. http://dx.doi.org/10.1016/00145793(88)80186-8. PMid:3169234.

Nascimento, G. M., Leandro, N. S. M., Café, M. B., Stringhini, J. H., Andrade, M. A., Martinez, K. L. A., Mello, H. H. C., \& Mascarenhas, A. G. (2014). Performance and intestinal characteristics of broiler chicken fed diet with glutamine in the diet without anticoccidials agents. Revista Brasileira de Saúde e Produção Animal, 15(3), 637-648. http://dx.doi.org/10.1590/S1519-99402014000300011.

National Research Council - NRC. (1994). Nutrient requirements of poultry (9th ed.). Washington, DC: The National Academics Press.

Paulino, M. T. F., Oliveira, E. M., Grieser, D. O., \& Toledo, J. B. (2019). Criação de frangos de corte e acondicionamento térmico em suas instalações: revisão. Pubvet, 13(2), 1-14. http://dx.doi.org/10.31533/pubvet.v13n3a280.1-14.

Rostagno, H. S., Albino, L. F. T., Donzele, J. L., Gomes, P. C., Oliveira, R. F., Lopes, D. C., Ferreira, A. S., Barreto, S. L. T., \& Euclides, R. F. (2011). Tabelas brasileiras para aves e suínos: composição de alimentos e exigências nutricionais. Viçosa: Imprensa Universitária.

SAS Institute. (2013). Statistical analysis systems user's guide: version 9.2. Cary: SAS Institute.

Silva, D. J., \& Queiroz, A. C. (2002). Análises de alimentos (métodos químicos ebiológicos) (3. ed.). Viçosa: Editora UFV.

Silva, G. C., Nascimento, M. R. B. M., Penha-Silva, N., Fernandes, E. A., Vilela, D. R., \& Souto, M. M. (2015). Suplementação com zinco e selênio em frangos de corte submetidos a estresse cíclico de calor. Revista Ceres, 62(4), 372-378. http://dx.doi.org/10.1590/0034-737X201562040006.

Souza, I. J., Oliveira, Z. B., Saretta, E., Rodrigues, L. R., Silva, C. M., \& Link, T. T. (2019). Análise do conforto térmico em modelos reduzidos de galpões agrícola. Ciência e Natura, 40,140-147. http://dx.doi.org/10.5902/2179460X35512.

Staub, L., Moraes, M. D. G., Santos, M. G., Komiyama, C. M., Gonçalves, N. S., Fernandes Junior, R. B., Ton, A. P. S., \& Roque, F. A. (2016). Ambiência interna e externa em galpão de frangos de corte nas diferentes épocas do ano e fases de criação. Pesquisas Agrárias e Ambientais, 4(3), 128-133. http://dx.doi.org/10.14583/2318-7670.v04n03a02.

Sunder, G. S., Panda, A. K., Gopinath, N. C. S., Rao, S. V. R., Raju, M. V. L. M., Reddy, M. R., \& Kumar, C. V. (2008). Effects of higher levels of zinc supplementation on performance, mineral availability, and immune competence in broiler chickens. Journal of Applied Poultry Research, 17(1), 79-86. http://dx.doi.org/10.3382/japr.2007-00029.

Trindade Neto, M. A., Kobashigawa, E., Namazu, L. B., Takeara, P., Araújo, L. F., \& Albuquerque, RB. (2010). Lisina digestível e zinco orgânico para frangos de corte machos na fase de 22 a 42 dias de idade. Revista Brasileira de Zootecnia, 39(11), 2460-2470. http://dx.doi.org/10.1590/S1516-35982010001100020.

Watford, M., \& Wu, G. (2005). Glutamine metabolism in uricotelic species: variation in skeletal muscle glutamine synthetase, L-glutaminase, glutamine levels and rates of protein synthesis. Comparative Biochemistry and Physiology, 140(4), 607-614. http://dx.doi.org/10.1016/j.cbpc.2004.12.009. PMid:15763516. 